\title{
MULTIDIMENSIONAL RISK AND RELIGIOSITY TOWARDS INDONESIAN MUSLIMS' SHARIA INVESTMENT DECISION
}

\author{
Irna Puji Lestari ${ }^{1}$, Wenang Ginanjar ${ }^{2}$ and Ari Warokka ${ }^{3}$ \\ ${ }^{1}$ Ministry Religious Affairs of Indonesia, Indonesia, irnaplestari@gmail.com \\ ${ }^{2}$ PT TASPEN Indonesia, Indonesia, wenang.ginanjar@gmail.com \\ ${ }^{3}$ Centro Internacional "Carlos V" - UAM, Spain, ari.warokka@gmail.com
}

\begin{abstract}
The decision-making process for Sharia investment needs to consider the individual's risk tolerance since every type of investment is closely attached to the risk-return trade-off. This study examines whether multidimensional risk tolerance and religiosity influence Sharia investment decisions. The study used 300 potential Muslim investors in Indonesia as the primary data source through an online survey with a convenience sampling method and analysed the data using Partial Least Squares Structural Equation Modelling (PLS-SEM). The results show that three multidimensional risks (risk propensity, risk attitude and risk capacity) have a significant effect on the Sharia investment decision. The research also tested the moderating effect of religiosity levels by performing Multi-Group Analysis (MGA) and found significant differences between risk propensity and sharia investment decisions among moderate and devout religious individuals.
\end{abstract}

Keywords: Multidimensional risk, Religiosity, Sharia investment decision. JEL classification: G11; G23; G32.

\author{
Article history: \\ Received : October 15, 2020 \\ Revised : January 14, 2021 \\ Accepted : March 8, 2021 \\ Available online : May 20, 2021
}

https://doi.org/10.21098/jimf.v7i2.1321 


\section{INTRODUCTION}

\subsection{Background}

Growth in Sharia investment in Indonesia has displayed quite an impressive, increasing wave (Barata, 2019). Based on the Global Islamic Economy Indicator Score (GIEI), Indonesia has seen a substantial rise in its ranking from tenth place in 2018 to fifth place in 2019, just before Saudi Arabia. Islamic stock market capitalisation grew at a compound annual growth rate of $9.54 \%$ from 2015 to 2019 (Otoritas Jasa Keuangan, 2019). At the same time, Sukuk recorded a compound annual growth rate of $25.81 \%$, and mutual funds expanded at a compound annual growth rate of $48.60 \%$. Table 1 contains data on Sharia Investment Assets in Indonesia. The instruments available within the Islamic capital market also align with national development goals. For example, the contribution made by Sukuk has been earmarked as infrastructure financing and for the development of public facilities in various regions across Indonesia. The total funds accumulated from the Sukuk Financing Project between 2013 and 2019 stood at IDR 90.79 trillion (Bank of Indonesia, 2019).

Table 1.

Sharia Investment Assets in Indonesia (2017-2019)

\begin{tabular}{lcccccc}
\hline \multirow{2}{*}{ Year } & \multicolumn{2}{c}{ Market Cap ISSI* } & \multicolumn{2}{c}{ Sukuk } & \multicolumn{2}{c}{ Sharia Mutual Fund } \\
\cline { 2 - 7 } & Rp (trillion) & Growth & Rp (trillion) & Growth & Rp (trillion) & Growth \\
\hline 2015 & $2,600.85$ & - & 307.48 & - & 11.02 & - \\
2016 & $3,170.06$ & $21.89 \%$ & 424.51 & $38.06 \%$ & 14.91 & $35.35 \%$ \\
2017 & $3,704.54$ & $16.86 \%$ & 567.30 & $33.64 \%$ & 28.31 & $89.83 \%$ \\
2018 & $3,666.69$ & $-1.02 \%$ & 668.47 & $17.83 \%$ & 34.49 & $21.83 \%$ \\
2019 & $3,744.82$ & $2.13 \%$ & 770.45 & $15.25 \%$ & 53.74 & $55.80 \%$ \\
\hline
\end{tabular}

Source: DJPPR Ministry of Finance and Financial Services Authority (OJK)

* Market Capitalisation of Indonesia Sharia Stock Index

In seeking to expand the investor base, the government of Indonesia has also introduced various innovative products to manage government securities, with the emergence of various Sukuk products offered from Rp1 million (Ministry of Finance Republic of Indonesia, 2019). The government has also enabled Muslims to take out a safe and productive investment instrument through its issuing of Cash Waqf Linked Sukuk (CWLS) in March 2020 (Directorate General of Budget Financing and Risk Management Ministry of Finance, 2020). This initiative has encouraged the growth of sharia investors in Indonesia, whose number has increased sharply over the last three years (as shown in Table 2). By the end of 2019, the total number of investors in Indonesia stood at around 68,599 (Otoritas Jasa Keuangan, 2019). 
Table 2.

Growth of Sharia Investors in Indonesia (2017-2019)

\begin{tabular}{lcc}
\hline Year & Number of investors & Growth \\
\hline 2017 & 23,207 & - \\
2018 & 44,536 & $91.91 \%$ \\
2019 & 68,599 & $54.03 \%$ \\
\hline
\end{tabular}

Source: Indonesia Stock Exchange and Financial Services Authority (OJK)

The Sharia capital market operates based on Islamic ethical teachings (Soemitra, 2016). Thus, in theory, a large Muslim population in a country should encourage growth in Sharia investment; however, in Indonesia, the growth in Sharia investment has not kept pace with the increasing size of the Muslim population. Based on the World Population Review (2020), Muslims accounted for around $87.2 \%$ of Indonesia's total population in 2020, totalling about 229 million people and with the potential for this to double in the future. Based on this population size, we can assume that only $0.03 \%$ of Muslims in Indonesia have invested in sharia assets, thus reflecting the significant potential for further sharia economic development in Indonesia.

However, every investment, whether sharia or conventional, carries exposure to some level of risk. While investors will seek to take advantage of investments, they will also consider the potential risks attached to investments (Ahmad, Warokka, \& Lestari, 2020). Muslim investors tend to be less willing to take risks in financial matters and have the lowest probability of investing in more volatile stocks and bonds (León \& Pfeifer, 2017). Instead, Muslims focus more on investing in savings contracts. Since the Qur'an fosters investments in real financial assets, investments in saving contracts appear to be more in line with real life than investing in other assets (León \& Pfeifer, 2017). In contrast, non-Muslim investors, Catholics for example, are associated with participating in gambling investment activities, such as lottery-stock premium options (Hodge, Rajgopal, \& Shevlin, 2010). As such, sharia investors may have a different perception of risk compared to conventional investors.

This risk perception suggests that risk tolerance affects how investors perceive an investment product's riskiness, thereby influencing their decision-making (Nguyen, Gallery, \& Newton, 2019). By understanding personal risk tolerance, investors are better placed to plan their investments (Løkka, 2014). Therefore, it is essential that individuals engage in a self-evaluation of their personal risk tolerance before making any investment decisions, including Sharia.

Much research has sought to investigate the way in which risk tolerance predicts investment decisions (Jamaludin \& Gerrans, 2015; Pak \& Mahmood, 2015). Interestingly, Cordell (2001) split risk tolerance into four dimensions: risk propensity, risk attitude, risk capacity and risk knowledge. Several behavioural finance researchers have also used this type of multidimensional risk to confirm the importance of risk tolerance assessment in making financial decisions (Ahmad et al., 2020; Ardehali, Paradi, \& Asmild, 2005; Cooper, Kingyens, \& Paradi, 2014). To provide another view in the literature regarding investment decision behaviour, especially in the sharia context, we use the Cordell (2001) approach to identify 
the individual's risk tolerance as a multidimensional construct. Furthermore, the limited existing studies in Islamic finance reveal a relative paucity of research examining how financial risk tolerance influences individual investment decisionmaking. It also assumes that this is due to a lack of specific factors that influence Muslims' nature, such as religiosity.

Religiosity shapes individuals' values and norms, affects their risk tolerance and influences their actions relating to personal finance decisions such as investments (Hess, 2012; Mahdzan, Zainudin, Hashim, \& Sulaiman, 2017). Religion therefore influences not only the level of risk that investors are willing to assume but also the nature of the investment that they choose (Mansour \& Jlassi, 2014). Some investors avoid non-sharia instruments because they are afraid of committing sinful acts (Firmansyah \& Andanawari, 2020). Therefore, we assume that religiosity plays a pivotal role in Muslims' investment decisions, with different levels of religiosity affecting their multidimensional risk and Sharia investment decisions.

\subsection{Objective}

Given the knowledge gap and the importance of assessing risk tolerance in making Sharia investment decisions, the objective of our study is to shed light on whether Muslims' multidimensional risk affects their investment decisionmaking. Specifically, its influence on investing in sharia financial assets, in addition to discerning the effect of religiosity. The study makes a threefold contribution in terms of responding to the following objectives. Firstly, it analyses the effect of multidimensional risks (i.e. risk propensity, risk attitude, risk capacity and risk knowledge) on Sharia investment decisions. Secondly, it explores the influence of religiosity on Sharia investment decisions. Finally, it examines whether different religiosity levels affect multidimensional risk and Sharia investment decisions.

\section{LITERATURE REVIEW}

\subsection{Sharia Investment Decision}

The term investment decision generally refers to an investor's choice of investment (Aren \& Aydemir, 2015; Aren \& Nayman Hamamci, 2020). In general, an investment decision is defined as a decision taken by an investor as to where, when, how and the amount of funds to invest in various financial instruments to generate income (Sindhu \& Kumar, 2014). Classical economic theories assume that individuals act rationally and consider all available information when making an investment decision (Njuguna, Namusonge, \& Kanali, 2016). Behavioural finance, therefore, assumes that when faced with uncertainty, individuals are unable to process the available information correctly and may behave irrationally, which is driven by the existence of behavioural biases (Byrne, Blake, \& Mannion, 2010). The investment decision could thus become subjective and influenced by the individual's psychological factors, such as their personality traits (Aren \& Nayman Hamamci, 2020; Gakhar, 2019; Mak \& Ip, 2017; Zhang \& Zheng, 2015), risk tolerance (Alleyne \& Tracey, 2011; Bajo, Barbi, \& Sandri, 2015; Gakhar, 2019), socio-demographic characteristics (Aren \& Aydemir, 2015; Bajo et al., 2015; Gakhar, 2019; Mak \& Ip, 2017) and other related factors. 
One popular theory to explain investment decisions is the prospect theory of Kahneman and Tversky (1979). According to this, the individual will make different decisions and exhibit different risk aversion levels over time, depending on their positions relative to a given target outcome. Various studies conducted in the field of Islamic finance have applied this prospect theory (Alam \& Tang, 2012; Imad, Razimi, \& Osman, 2017; Mantine \& Jais, 2019; Sameen, 2017).

Sharia investment principles emphasise ethical investing that is conducted in line with the Islamic principles that govern every facet of the lives of all Muslims (Sherif \& Lusyana, 2016). Islamic financial instruments with fixed incomes such as preferred stocks, bonds, options or other derivatives are unacceptable, as they promise a fixed rate of return and grant no voting rights (Walkshäusl \& Lobe, 2012).

The most distinct characteristic of Sharia investments is the prohibition of riba (interest), gharar (uncertainty), maysir (gambling) and anything that is considered haram (prohibited) in Islamic teachings (Abduh \& Hussin, 2018). Investment is a business activity that contains risk because it has an uncertain and precarious return. Meanwhile, riba is a less risky business activity because the return is derived from interest, which is relatively fixed and stable (Soemitra, 2016). Those who invest in Sharia investments also tend to be very concerned with 'ethical investing' (Sherif \& Lusyana, 2016); to this end, they avoiding investing in businesses involved in alcohol, gambling, pork-related products, tobacco and weapons. Arguably, these rules are in place mainly to protect the interest of all parties involved in the market, in the objective of the Sharia or maqasid al-Sharia (Dusuki \& Abozaid, 2007).

In Indonesia, sharia investment began when PT Danareksa Investment Management issued Sharia Mutual Funds on July 3, 1997. Furthermore, the Jakarta Islamic Index was launched on July 3, 2000 with the aim of guiding investors seeking to invest funds in Sharia financial assets. Indonesia's sharia investment landscape then continued to grow with the issuance of the first Islamic Bonds in early September 2002, using the mudharabah covenant (www.ojk.go.id). Up to now, the sharia securities issued in the Indonesian capital market are sharia stocks, Sukuk (comprising Sukuk issued by both corporations and the government) and sharia mutual funds.

\subsection{Multidimensional Risk}

The concept of multidimensional risk was first introduced by Cordell (2001), who classified risk tolerance into various multidimensional constructs, including risk propensity, risk attitude, risk capacity and risk knowledge. Many researchers have since developed the concept in assessing risk tolerance (Holzhauer, Lu, McLeod, \& Wang, 2016; Wahl \& Kirchler, 2020). Generally, scholars define risk tolerance as the maximum amount of uncertainty someone is willing to accept when making a financial decision (Grable \& Joo, 2004). To truly understand an investor's financial risk tolerance, this multidimensional construct must be measured separately (Cordell, 2001). 


\subsubsection{Risk Propensity}

Risk propensity refers to the idea of the objective risk of an investor's allocation predisposition; that is, the exchange between risk and return that a person is willing to accept (Cordell, 2001). Sitkin and Weingart (1995) define risk propensity as the current tendency of decision-makers to take or avoid risks that can change over time, based on experience. Risk propensity varies between individuals (King \& Slovic, 2014). Bucciol and Miniaci (2018) found that investor risk propensity increases during periods of economic growth and positive stock market returns. Kahneman and Tversky (1979) argued that an individual is irrational and has an unpredictable risk propensity when faced with risky investment decisions.

\subsubsection{Risk Attitude}

Risk attitude refers to the willingness to incur monetary risk (Cordell, 2001). Some researchers define risk attitude as 'risk-taking behaviour' (Kannadhasan, 2015; Lampenius \& Zickar, 2005). Risk-taking attitude is based on risk perception from an investor's perspective. According to Cordell (2001), it is categorised as a psychological attitude, so that risk attitude, in turn, determines the investment style (Pak \& Mahmood, 2015). Risk attitudes play a role in various investment decision-making situations, including when the decision-maker acts in accordance with preferences other than their expected utility and where decisions are made over various alternatives (Gustafsson, 2015). Weber, Blais, and Betz (2002) stated that a person's risk attitude is a descriptive explanation for the shape of the utility function that is assumed to underpin the risky choices that an individual makes in return for their desired outcomes.

\subsubsection{Risk Capacity}

Risk capacity is an individual's financial ability to incur risks (Cordell, 2001). Brayman (2012) conceptualises risk capacity as the level of risk someone is able to take, where the term 'able to take' is linked to a specific goal that the individual has in mind and is also given a context. It is therefore impossible to measure the notion of 'able to take' unless someone has it. Bosner and Lakehal-Ayat (2008) show that risk capacity can be determined objectively, such as by the individual's income, age, financial stability, family situation and similar quantifiable factors. Individuals can have an identical risk capacity if they have identical incomes, ages or financial situations. Nobre, Grable, da Silva, and Nobre (2018) state that risk capacity changes over time, but capacity factors tend to be stable over short periods, which corresponds to real-world risky choices.

\subsubsection{Risk Knowledge}

Risk knowledge refers to an individual's understanding of risk and the exchange of risks and returns (Cordell, 2001). The amount, source and nature of the information that individuals receive about investing are likely to influence their financial decisions (Njuguna et al., 2016). An investor is more likely to engage in decisionmaking behaviour if they feel more competent (Ackert \& Deaves, 2010). Thus, 
poor risk-taking decisions are made due to investors' lack of knowledge (Wang, 2009), especially when these involve investment risk concepts such as standard deviation, covariance, beta, Monte Carlo analysis and portfolio performance measures (Cordell, 2001).

\subsection{Religiosity}

Religiosity is a factor that influences individual investment decisions in the Islamic context (Hess, 2012; Muhamad, Devi, \& Mu'min, 2006; Saputra, Natassia, \& Utami, 2020). Religious beliefs and practices routinely have a massive impact on an individual's ethical, social, demographic, economic, saving and financial behaviour. This degree of religious beliefs and practices can be interpreted as religiosity. Iddagoda and Opatha (2017) define religiosity as the extent to which a particular person believes in and glorifies the relevant religious creator, god or goddess, then practises the relevant teachings and participates in the relevant activity.

\subsection{Previous Study}

Previous studies have shown that individuals' investment behaviour is related to their financial risk tolerance (Annamalah, Raman, Marthandan, \& Logeswaran, 2019; Jacobs-Lawson \& Hershey, 2005; Jamaluddin \& Gerrans, 2015; Pak \& Mahmood, 2015). For instance, risk-tolerant investors nearing retirement do not reduce their bond allocations to buy more stock (Hariharan, 2000). Risk tolerance in this study will be separated into and measured as risk propensity, risk attitude, risk capacity and risk knowledge.

Alleyne and Tracey (2011) found that risk propensity contributes significantly to the intention to invest. Hamid, Rangel, Taib, and Thurasamy (2013) show that risk propensity affects risk investment decisions. However, Combrink and Lew (2019) found no significant relationship between risk propensity and decisionmaking behaviour. They found no relationship between how investors rated their successes and the propensity to take a risk or choose riskier options when faced with two choices (Combrink \& Lew, 2019).

Previous studies have also shown that an individual's investment behaviour is associated with risk attitude (Annamalah et al., 2019; Gakhar, 2019; Kemp, Chan, Chen, \& Helton, 2018). Raut, Das, and Kumar (2018) found attitude towards risk to be the most significant predictor for the investment intention of Indian investors. Those who could afford to lose and were willing to take financial risks had favourable attitudes towards investment and were more likely to invest (Raut, Das, \& Kumar, 2018). Gakhar (2019) noted that risk attitude has a significant difference in medium-risk investment instruments taken by investors. Investors' performance can largely be explained by their tendency to hold stocks that have more value during a bullish phase and high-risk stocks during a bearish phase (Gakhar, 2019).

Hymavathi, Anusha, and Priya (2020) studied the relationship between risk capacity and investment decisions and found that risk tolerance capacity regarding equity had a negative relationship with investment decisions. Satvaya (2017) also 
found a difference among retail investors regarding financial risk-taking capacity in their investment. Annamalah, Raman, Marthandan, and Logeswaran (2019) studied risk-taking behaviour in terms of its capacity among investors and found that it had an influence on investors' investment behaviours, as indicated by the ability to tolerate more risks due to investor financial resources.

As for risk knowledge, we were unable to find any research that explicitly examined this. However, we assume that risk knowledge is part of financial knowledge, so we connected previous research that links financial knowledge and investment decision behaviour, such as the studies by Njuguna, Namusonge, and Kanali (2016), Raut (2020), Octarina, Hartoyo, and Beik (2019) and Popat and Pandya (2018). Raut (2020) found a significant effect between financial knowledge and investment decision-making. His research makes a significant contribution to financial studies regarding the individual investor's decision-making. Octarina et al. (2019) analysed the investment intention of sharia mutual fund products in Indonesia and found that knowledge had a significant influence. Njuguna et al. (2016), meanwhile, found that people with financial knowledge who understood the difference between mutual funds and stocks were willing to take risks as part of the investment decision-making process.

Many kinds of research also linked investment decisions in Islamic finance to religiosity (Abduh \& Hussin, 2018; Hess, 2012; Jamaludin, 2013; Mahdzan et al., 2017). Abduh and Hussin (2018) showed that religiosity had a positive significant effect on the investment decision-making process of Malaysian investors. The higher an investor's religiosity level, the more likely they were to opt for sharia investment schemes over conventional schemes. Muhamad, Devi, and Mu'min (2006) found that the level of religiosity among 262 Malay Muslims significantly influenced their investment decision-making. A qualitative study by Goel, Dwivedi, and Jain (2019) found that Islamic religious principles affected the investment behaviour of Indian Muslims.

Several studies have also found that religiosity is related to risk tolerance (Hess, 2012; Mahdzan et al., 2017; Saputra et al., 2020). Saputra, Natassia, and Utami (2020) found that religiosity has a significant positive effect on loss aversion, especially when investing in stock types of securities. At the same time, religiosity with loss aversion has a negative and significant effect on investment decisions. While Mahdzan, Zainudin, Hashim, and Sulaiman (2017) found that Muslim investors' risk propensity to hold safe portfolios was influenced by their religiosity levels, especially their sense of virtue and morality, as taught in Islam. Religious teachings forbid speculation through investing because it contains the value of usury and risk will thus reduce Indonesian Muslim investors' willingness to invest, especially in stock (Saputra et al., 2020). The relation between religiosity, risk tolerance and religious-based investment decisions can somehow reduce or increase the relationship between multidimensional risk and investment decision. Hence, we suggest that religiosity has a moderating effect. 


\section{METHODOLOGY}

\subsection{Data}

This research employed primary data collected from a structured questionnaire and used the convenience sampling method with the following sample criteria: Muslim investors in Indonesia, with a regular monthly income and access to online investment. We distributed the questionnaire through an online channel, namely the Telegram group of the Sharia investor community (@syariahsaham), which has more than 11,000 members across Indonesia. To ensure a comparable level of religiosity, we also recruited respondents from the most religious Sharia investor, namely government employees of the Ministry of Religious Affairs of Indonesia, where a total of 98 respondents joined the Sukuk Related programme to Cash Waqf (CWLS). We assumed that they are most religious since they work in an institution that upholds religious values as a work culture.

Concerning the sample size, we employed the recommendation by Hair, Black, Babin, and Anderson (2010) that a sample size of $\leq 7$ constructs with no unidentified construct and multiple unidentified requires between 150 and 300. It took around four months (May-August 2020) to secure the minimum sample size. Hence, in this study, of the 378 respondents who completed the survey, only 300 met the criteria and were included in the research sample.

\subsection{Research Instrument}

The survey questionnaire of this study consisted of seven sections. In Section 1, the respondents completed a simple demographic survey. Section 2 identified the respondents' investment decisions in Sharia assets by adopting the measure developed by Duqi and Al-Tamimi (2019) and Lone (2016). We also added additional questions about sharia investment attractiveness. In Sections 3 to 6, the respondents provided information related to a self-evaluation of their risk propensity, risk attitude, risk capacity and risk knowledge using the Risk Screening on the Financial Market (RISC-FM) scale adopted from Wahl and Kirchler (2020). These sections also included additional questions using a risk tolerance scale; for risk propensity this was adopted from Alleyne and Tracey (2011), and for risk capacity it was adopted from Injodey and Alex (2011). The final section, Section 7 , asked about the respondents' religiosity as measured based on Iddagoda and Opatha (2017).

To enhance the validity and reliability of the measures, the instruments used in this study matched those employed in previous studies wherever possible. We also conducted a pilot study among 30 respondents to ensure that the questions and their sequence were comprehensible.

\subsection{Model Development}

This study proposes a model consisting of four constructs of multidimensional risk as the independent variables relating to Sharia investment decisions (the dependent variable), where religiosity moderates the relation. Figure 1 visualises the model, with the following hypotheses deemed to be of value for testing. 


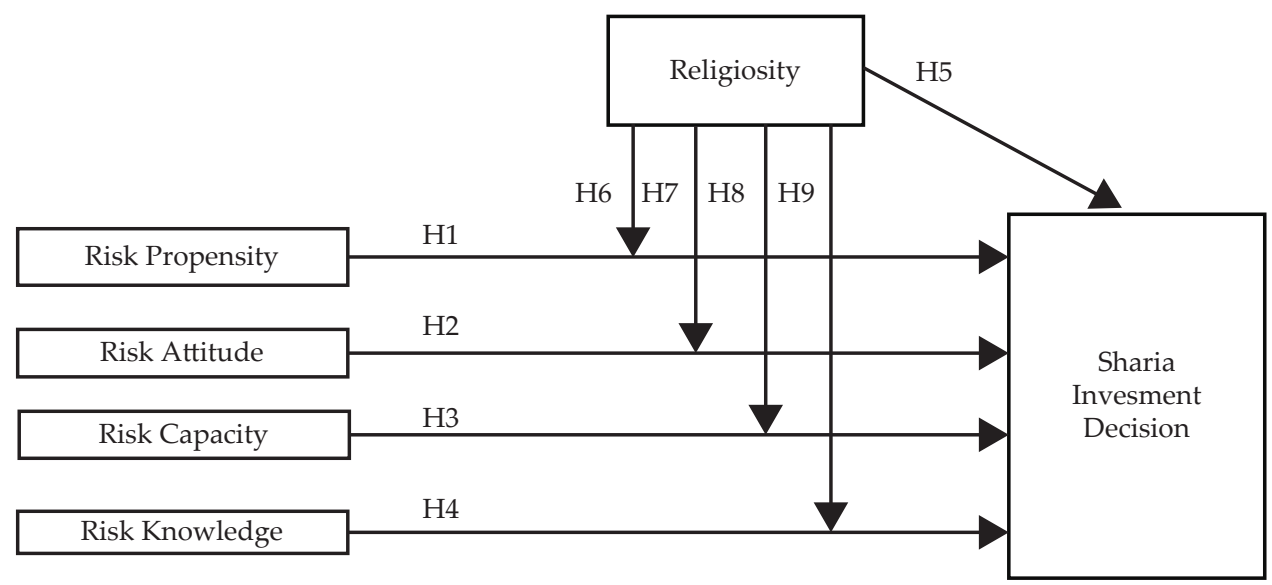

Figure 1.

Research Model

H1 : Risk Propensity affects the Sharia Investment Decision

H2 : Risk Attitude affects the Sharia Investment Decision

H3 : Risk Capacity affects the Sharia Investment Decision

H4 : Risk Knowledge affects the Sharia Investment Decision

H5 : Religiosity affects the Sharia Investment Decision

H6 : Different levels of religiosity affect the influence of Risk Propensity on the Sharia Investment Decision

H7 : Different levels of religiosity affect the influence of Risk Attitude on the Sharia Investment Decision

H8 : Different levels of religiosity affect the influence of Risk Capacity on the Sharia Investment Decision

H9 : Different levels of religiosity affect the influence of Risk Knowledge on the Sharia Investment Decision

\subsection{Method}

We used Partial Least Squares (PLS) as the analysis technique in this study, which is a structural equation method (SEM) based on variance. PLS-SEM was chosen due to its suitability for explanative or predictive studies (Henseler, Hubona, \& Ray, 2016) and was used for its ability to assess complex models that consist of mediating and moderating variables (Ghozali \& Latan, 2015). The choice of this method was also heavily influenced by the measurement of the dependent variable, which is all reflective but compatible for measurement by PLS-SEM (Hair, Sarstedt, Hopkins, \& Kuppelwieser, 2014).

PLS comprises three stages of analysis: measurement model evaluation, structural model evaluation and hypothesis testing. Measurement model evaluation was used to test the validity and reliability of the indicators through convergent validity, discriminant validity and construct reliability. The study was exploratory research; hence, based on Hair et al.'s (2010) recommendation, the measurement model of this study was further assessed based on a cut of 
value of the acceptable outer loadings $>0.6$, average variance extracted (AVE) $>$ 0.5 , composite reliability $(\mathrm{CR})>0.7$ and Cronbach's alpha $>0.7$. For discriminant validity, we used the Fornell-Larcker criterion by comparing the square root of the AVE with the correlation of latent constructs (Hair et al., 2014).

Structural model evaluation was used to ensure the structural model built was accurate by evaluating the coefficient of determination (R-squared), crossvalidated redundancy (Q-squared) and path coefficient. R-squared values of $0.75,0.50$ and 0.25 for endogenous latent variables can be respectively described as substantial, moderate and weak (Hair et al., 2014). A Q-squared value greater than zero indicates that the path model has predictive relevance (Hair et al., 2014). Path coefficient evaluation was conducted as part of the hypothesis testing by analysing the t-statistic value and p-value for each path coefficient. With a t-table value for alpha 5\% (two-tailed) of 1.96, a hypothesis was accepted if the t-statistics $>$ t-table and p-value $<0.05$ (Ghozali \& Latan, 2015).

We used Multi-Group Analysis in PLS (PLS-MGA) to test the moderating effect of religiosity. Multi-group analysis (MGA) is a type of moderator analysis where the moderator variable is categorical and is assumed to potentially affect all relationships in the inner model (Hair et al., 2014). The moderator variable of religiosity was thus grouped into three categories: casual, moderate and devout, following the studies of Jamaludin (2013) and Mahdzan et al. (2017). All data were processed using SmartPLS software version 3.3.

\section{RESULTS AND ANALYSIS}

\subsection{Results}

\subsubsection{Demographics of Respondents}

This study involved 300 Muslim investor respondents in Indonesia who were gathered using convenience sampling. The demographic information of the respondents is given in Table 3 .

Table 3.

Demographics of Respondents

\begin{tabular}{lcc}
\hline Demographic & Frequency & \% \\
\hline Age (in years) & & 1.3 \\
Below 25 & 4 & 54.7 \\
$25-35$ & 164 & 41.0 \\
$36-50$ & 123 & 3.0 \\
Above 50 & 9 & \\
Gender & & 55.0 \\
Male & 165 & 45.0 \\
Female & 135 & \\
Marital Status & & 24.7 \\
Single & 74 & 74.0 \\
Married & 222 & 1.3 \\
Divorced/Widowed & 4 & \\
\hline
\end{tabular}


Table 3.

Demographics of Respondents (Continued)

\begin{tabular}{lcc}
\hline Demographic & Frequency & \% \\
\hline Education Level & 10 & 3.3 \\
High school or equivalent & 10 & 3.3 \\
Diploma & 177 & 59.0 \\
Bachelor degree & 103 & 34.3 \\
Master/Doctoral or above & & \\
Occupation & 142 & 47.3 \\
Private Employee & 137 & 45.7 \\
Public/Government Employee & 21 & 7.0 \\
Self-employed/Businessman & & \\
Monthly income (before tax) & 13 & 4.3 \\
Below Rp 3,000,000 & 37 & 12.3 \\
Rp 3,000,000 - Rp 4,999,999 & 134 & 44.7 \\
Rp 5,000,000 - Rp 9,999,999 & 65 & 21.7 \\
Rp 10,000,000 - Rp 19,999,999 & 51 & 17.0 \\
Above Rp 20,000,000 & & \\
Domicile & 183 & 61.0 \\
Jakarta & 40 & 13.3 \\
Bekasi & 37 & 12.3 \\
Tangerang & 13 & 4.3 \\
Bogor & 12 & 4.0 \\
Depok & 15 & 5.0 \\
Others & & \\
\hline
\end{tabular}

The majority of the respondents were aged between 25 and 35 years old $(54.7 \%)$, male (55\%) and married (74\%). The respondents also predominantly held bachelor degrees as their educational background (59\%) and worked in private companies (47.3\%). The dominant monthly income of the respondents in the study was between Rp5,000,000 and Rp9,999,999 (44.7\%), and most of the respondents lived in the Jakarta area (61\%).

\subsubsection{Descriptive Analysis}

The six variables of risk propensity, risk attitude, risk capacity, risk knowledge, religiosity and Sharia investment decision are the observed variables. To describe each variable statistically, we divided each variable into three categories. To perform this categorisation, we first took the mean score of all items in this study for all respondents. We then computed the grand mean score and standard deviation of each variable. Summarised descriptive statistics for the variables are shown in Table 4. 
Table 4.

Descriptive Statistics of Variables

\begin{tabular}{|c|c|c|c|c|c|}
\hline Variables & & Items & Mean & $\begin{array}{l}\text { Grand } \\
\text { Mean }\end{array}$ & SD \\
\hline \multirow{13}{*}{$\begin{array}{l}\text { Sharia } \\
\text { Investment } \\
\text { Decision } \\
\text { (Duqi \& } \\
\text { Al-Tamimi, } \\
\text { 2019; Lone, } \\
\text { 2016) }\end{array}$} & SID1 & $\begin{array}{c}\text { Sharia investment reduces risk versus conventional } \\
\text { investment }\end{array}$ & 3.69 & \multirow{13}{*}{3.702} & \multirow{13}{*}{1.004} \\
\hline & SID2 & Investment in Sharia is for security, not return & 3.86 & & \\
\hline & SID3 & Sharia investment promotes Islamic values & 3.88 & & \\
\hline & SID4 & Sharia investment has no Gharar (more risk) & 3.76 & & \\
\hline & SID5 & $\begin{array}{l}\text { Sharia investment practice avoids forbidden } \\
\text { businesses in Islam }\end{array}$ & 3.76 & & \\
\hline & SID6 & Sharia investment is free from riba & 4.07 & & \\
\hline & SID7 & $\begin{array}{l}\text { Sharia investment can avoid maysir and qimar } \\
\text { (gambling) }\end{array}$ & 4.01 & & \\
\hline & SID8 & Religious satisfaction from Sharia investment & 4.07 & & \\
\hline & SID9 & Percentage of income will invest in Sharia & 2.82 & & \\
\hline & SID10.1 & The attractiveness of Sharia Mutual Funds & 3.71 & & \\
\hline & SID10.2 & The attractiveness of Sharia Stocks & 3.49 & & \\
\hline & SID10.3 & The attractiveness of Sukuk (corporate) & 3.47 & & \\
\hline & SID10.4 & The attractiveness of Sukuk (government) & 3.54 & & \\
\hline \multirow{6}{*}{$\begin{array}{l}\text { Risk } \\
\text { Propensity } \\
\text { (Wahl \& } \\
\text { Kirchler, } \\
\text { 2020; } \\
\text { Alleyne } \\
\text { \& Tracey, } \\
\text { 2011) }\end{array}$} & $\mathrm{RP} 1$ & $\begin{array}{l}\text { Choosing more or less risky alternatives based on } \\
\text { the reliable assessment of others }\end{array}$ & 3.21 & \multirow{6}{*}{3.083} & \multirow{6}{*}{1.067} \\
\hline & RP2 & $\begin{array}{c}\text { Choosing more or less risky alternatives that have } \\
\text { a significant impact on future }\end{array}$ & 3.19 & & \\
\hline & RP3 & $\begin{array}{l}\text { Choosing more or less risky alternatives that rely } \\
\text { on analyses in high technical complexity }\end{array}$ & 3.27 & & \\
\hline & RP4 & $\begin{array}{c}\text { Making a decision when realising that relevant } \\
\text { analysis has been done but some information is } \\
\text { missing }\end{array}$ & 2.67 & & \\
\hline & RP5 & $\begin{array}{c}\text { Investing } 10 \% \text { of wealth very speculatively in very } \\
\text { risky investment }\end{array}$ & 3.11 & & \\
\hline & RP6 & Reinvesting in risky assets after considerable loss & 3.04 & & \\
\hline \multirow{6}{*}{$\begin{array}{l}\text { Risk } \\
\text { Attitude } \\
\text { (Wahl \& } \\
\text { Kirchler, } \\
\text { 2020) }\end{array}$} & RA1 & $\begin{array}{l}\text { I am ready to accept losses to achieve gains in the } \\
\text { long run }\end{array}$ & 2.99 & \multirow{6}{*}{2.697} & \multirow{6}{*}{1.067} \\
\hline & RA2 & $\begin{array}{l}\text { High profits are attractive to me, although this } \\
\text { means that I must also take a high risk }\end{array}$ & 3.03 & & \\
\hline & RA3 & $\begin{array}{l}\text { I like to take the risk of losing money when there is } \\
\text { a chance to win money }\end{array}$ & 2.75 & & \\
\hline & RA4 & $\begin{array}{l}\text { I am ready to invest more than a quarter of my } \\
\text { financial assets in a risky investment }\end{array}$ & 2.69 & & \\
\hline & RA5 & $\begin{array}{c}\text { I feel more comfortable putting my money in a } \\
\text { savings account than investing it in the capital } \\
\text { market* }\end{array}$ & 2.38 & & \\
\hline & RA6 & $\begin{array}{l}\text { I prefer to save money in a savings account } \\
\text { because I know how much money I have at my } \\
\text { disposal in the future* }\end{array}$ & 2.34 & & \\
\hline
\end{tabular}


Table 4.

Descriptive Statistics of Variables (Continued)

\begin{tabular}{|c|c|c|c|c|c|}
\hline Variables & & Items & Mean & $\begin{array}{l}\text { Grand } \\
\text { Mean }\end{array}$ & SD \\
\hline \multirow{7}{*}{$\begin{array}{l}\text { Risk } \\
\text { Capacity } \\
\text { (Wahl \& } \\
\text { Kirchler, } \\
\text { 2020; } \\
\text { Injodey \& } \\
\text { Alex, 2011) }\end{array}$} & $\mathrm{RC} 1$ & $\begin{array}{l}\text { If something goes wrong financially, I can adapt } \\
\text { easily }\end{array}$ & 3.59 & \multirow{7}{*}{3.568} & \multirow{7}{*}{0.945} \\
\hline & $\mathrm{RC} 2$ & $\begin{array}{l}\text { From time to time, the value of my investments can } \\
\text { decrease without me getting nervous }\end{array}$ & 3.57 & & \\
\hline & $\mathrm{RC} 3$ & $\begin{array}{l}\text { After deducting all fixed costs, my monthly income } \\
\text { suffices to invest a higher amount of money }\end{array}$ & 3.23 & & \\
\hline & $\mathrm{RC} 4$ & $\begin{array}{c}\text { I can wait several years for my investments to } \\
\text { recover from the effects of a poor economic } \\
\text { situation }\end{array}$ & 3.42 & & \\
\hline & RC5 & $\begin{array}{l}\text { I earn a regular monthly income, which ensures } \\
\text { my standard of living }\end{array}$ & 3.86 & & \\
\hline & RC6 & $\begin{array}{l}\text { I have enough money to fulfil my financial } \\
\text { obligation }\end{array}$ & 3.94 & & \\
\hline & RC7 & $\begin{array}{l}\text { I have adequate insurance coverage to cover all } \\
\text { possible risks }\end{array}$ & 3.38 & & \\
\hline \multirow{6}{*}{$\begin{array}{l}\text { Risk } \\
\text { Knowledge } \\
\text { (Wahl \& } \\
\text { Kirchler, } \\
\text { 2020) }\end{array}$} & RK1 & $\begin{array}{l}\text { Before investing, I try to gather information about } \\
\text { different investment alternatives. }\end{array}$ & 4.13 & \multirow{6}{*}{3.518} & \multirow{6}{*}{0.966} \\
\hline & RK2 & I am familiar with most financial products & 3.58 & & \\
\hline & RK3 & $\begin{array}{l}\text { It is challenging to understand how financial } \\
\text { transactions are processed }\end{array}$ & 3.07 & & \\
\hline & RK4 & I am well aware regarding money matters & 3.46 & & \\
\hline & RK5 & $\begin{array}{l}\text { I am quite familiar with several terms in } \\
\text { investment risk }\end{array}$ & 3.64 & & \\
\hline & RK6 & $\begin{array}{c}\text { I understand the concepts of systematic risk and } \\
\text { unsystematic risk }\end{array}$ & 3.22 & & \\
\hline \multirow{6}{*}{$\begin{array}{l}\text { Religiosity } \\
\text { (Iddagoda } \\
\text { \& Opatha, } \\
\text { 2017). }\end{array}$} & REL1 & $\begin{array}{l}\text { I believe in what the founder of my religion } \\
\text { preached through the Qur'an and Hadiths }\end{array}$ & 3.96 & \multirow{6}{*}{3.953} & \multirow{6}{*}{0.831} \\
\hline & REL2 & $\begin{array}{l}\text { I have a very positive feeling and respect for } \\
\text { religion and religious personages (the prophet, } \\
\text { religious leaders, etc.) }\end{array}$ & 4.12 & & \\
\hline & REL3 & $\begin{array}{c}\text { I practise what the founder of my religion } \\
\text { preached }\end{array}$ & 3.88 & & \\
\hline & REL4 & $\begin{array}{l}\text { I very often go to religious places (such as mosque) } \\
\text { to worship/pray }\end{array}$ & 3.95 & & \\
\hline & REL5 & $\begin{array}{l}\text { I am more concerned about practising what the } \\
\text { Qur'an prescribes and engaging in a wholehearted } \\
\text { way }\end{array}$ & 3.98 & & \\
\hline & REL6 & $\begin{array}{l}\text { I participate in social activities which have a } \\
\text { religious significance (such as recitation, dhikr, etc.) }\end{array}$ & 3.84 & & \\
\hline
\end{tabular}

Note $={ }^{*}$ unfavourably items

Having obtained the descriptive statistics output for all items, we then categorised each variable based on three criteria. Respondents with a mean score greater than or equal to 0.5 standard deviations of the mean score were considered as 'High' ( $x \geq$ mean+0.5 SD). Respondents with a mean score less than or equal to 
0.5 standard deviations of the mean score were considered as 'Low' ( $x \leq$ mean$0.5 \mathrm{SD})$. Respondents with a mean score in between were considered 'Moderate' (mean-0.5 SD $\leq x \leq$ mean+0.5 SD). Meanwhile, religiosity was categorised as Casual (low), Moderate or Devout (high). The categorisation of all variables is given in Table 5.

Table 5.

Categorisation of Variables

\begin{tabular}{lcccccc}
\hline \multirow{2}{*}{ Variables } & \multicolumn{2}{c}{ Low/ Casual } & \multicolumn{2}{c}{ Moderate } & \multicolumn{2}{c}{ High/ Devout } \\
\cline { 2 - 7 } & $\mathbf{f}$ & $\mathbf{\%}$ & $\mathbf{f}$ & $\mathbf{\%}$ & $\mathbf{f}$ & $\%$ \\
\hline Sharia Investment Decision & 64 & 21.33 & 151 & 50.33 & 85 & 28.33 \\
Risk Propensity & 96 & 32.00 & 112 & 37.33 & 92 & 30.67 \\
Risk Attitude & 57 & 19.00 & 165 & 55.00 & 78 & 26.00 \\
Risk Capacity & 57 & 19.00 & 186 & 62.00 & 57 & 19.00 \\
Risk Knowledge & 68 & 22.67 & 185 & 61.67 & 47 & 15.67 \\
Religiosity & 78 & 26.00 & 145 & 48.33 & 77 & 25.67 \\
\hline
\end{tabular}

We classify Sharia investment decision level as the 'level of sharia investment behaviour' that indicates a respondent's encouragement, preferences and intention to invest in Sharia over other, alternative investments. The results show that most of the respondents $(50.33 \%+28.33 \%)$ have a moderate to high level of Sharia investment behaviour. We also found that most of the respondents $(32 \%+37.33 \%)$ have a low to moderate level of risk propensity, and most $(55 \%+26 \%)$ also have a moderate to high level of risk attitude. As for the level of risk capacity, some respondents showed a moderate level (62\%), while low and high risk capacities were shown in the same proportions of respondents (both at 19\%). The majority of respondents $(22.67 \%+61.67 \%)$ also showed a low to moderate level of risk knowledge. The levels of religiosity among the respondents were in the proportions of $26 \%$ casual, $48.33 \%$ moderate and $25.67 \%$ devout. This finding indicates that as many as $74 \%$ of the respondents had a moderate to high (devout) level of religiosity.

To enrich the findings of the descriptive analysis, we conducted a crosstabulation using Pearson's chi-square tests (Table 6). This was also used to investigate the association between the level of Sharia investment behaviour and the level of other variables. The results showed a statistically significant value $(p<0.05)$, thus indicating a relationship between the four multidimensional risks and religiosity and its effect on Sharia investment decisions. 
Table 6.

Cross-tabulation of Variables

\begin{tabular}{|c|c|c|c|c|c|c|c|c|}
\hline \multirow{2}{*}{ Level } & \multicolumn{6}{|c|}{ Sharia Investment Behaviour } & \multirow{2}{*}{$\lambda^{2}$} & \multirow{2}{*}{$\mathbf{P}$} \\
\hline & & Low & & derate & & High & & \\
\hline \multicolumn{9}{|l|}{ Risk Propensity } \\
\hline Low & 5 & $1.67 \%$ & 60 & $20.00 \%$ & 31 & $10.33 \%$ & & \\
\hline Moderate & 17 & $5.67 \%$ & 62 & $20.67 \%$ & 33 & $11.00 \%$ & $50.613^{\mathrm{a}}$ & 0.000 \\
\hline High & 42 & $14.00 \%$ & 29 & $9.67 \%$ & 21 & $7.00 \%$ & & \\
\hline \multicolumn{9}{|l|}{ Risk Attitude } \\
\hline Low & 0 & $0.00 \%$ & 34 & $11.33 \%$ & 23 & $7.67 \%$ & & \\
\hline Moderate & 25 & $8.33 \%$ & 94 & $31.33 \%$ & 46 & $15.33 \%$ & $58.924^{\mathrm{a}}$ & 0.000 \\
\hline High & 39 & $13.00 \%$ & 23 & $7.67 \%$ & 16 & $5.33 \%$ & & \\
\hline \multicolumn{9}{|l|}{ Risk Capacity } \\
\hline Low & 34 & $11.33 \%$ & 14 & $4.67 \%$ & 9 & $3.00 \%$ & & \\
\hline Moderate & 23 & $7.67 \%$ & 112 & $37.33 \%$ & 51 & $17.00 \%$ & $68.102^{\mathrm{a}}$ & 0.000 \\
\hline High & 7 & $2.33 \%$ & 26 & $8.00 \%$ & 24 & $8.67 \%$ & & \\
\hline \multicolumn{9}{|l|}{ Risk Knowledge } \\
\hline Low & 34 & $11.33 \%$ & 30 & $10.00 \%$ & 4 & $1.33 \%$ & & \\
\hline Moderate & 23 & $7.67 \%$ & 111 & $37.00 \%$ & 51 & $17.00 \%$ & $78.855^{\mathrm{a}}$ & 0.000 \\
\hline High & 7 & $2.33 \%$ & 10 & $3.33 \%$ & 30 & $10.00 \%$ & & \\
\hline \multicolumn{9}{|l|}{ Religiosity } \\
\hline Casual & 40 & $13.33 \%$ & 30 & $10.00 \%$ & 8 & $2.67 \%$ & & \\
\hline Moderate & 19 & $6.33 \%$ & 97 & $32.33 \%$ & 29 & $9.67 \%$ & $105.026^{\mathrm{a}}$ & 0.000 \\
\hline Devout & 5 & $1.67 \%$ & 24 & $8.00 \%$ & 48 & $16.00 \%$ & & \\
\hline
\end{tabular}

Notes: $\mathrm{df}=4 ; \mathrm{n}=300$

From the total of 300 respondents, an interesting finding is that the majority of respondents with a low risk propensity $(20 \%+10.33 \%)$ and low risk attitude $(11.33 \%+7.67 \%)$ displayed a moderate to high level of Sharia investment behaviour. Otherwise, most respondents with a high risk propensity $(14 \%+9.67 \%)$ and high risk attitude $(13 \%+7.67 \%)$ showed low to moderate Sharia investment behaviour. Moreover, most of the respondents with low risk capacity $(11.33 \%+4.67 \%)$ and low risk knowledge $(11.33 \%+10 \%)$ showed a low to moderate level of Sharia investment behaviour. In contrast, the majority of respondents with high risk capacity $(8 \%+8.67 \%)$ and high risk knowledge $(3.33 \%+10 \%)$ showed a moderate to high level of Sharia investment behaviour.

In terms of religiosity, the majority of respondents who identified as casually religious showed a low to moderate level of Sharia investment behaviour $(13.33 \%+10 \%)$, the majority of moderately religious respondents showed a moderate to high level of Sharia investment behaviour $(32.33 \%+9.67 \%)$, and the majority of devoutly religious respondents showed a moderate to high level of Sharia investment behaviour $(8 \%+16 \%)$.

We also gathered information regarding the percentage of income that respondents were willing to allocate to sharia investment. Figure 2 shows that most of the Muslim respondents (119 respondents; $39.67 \%$ ) were willing to allocate $10.1 \%$ to $15 \%$ of their income to sharia investment, while only a few respondents (10 respondents; $3.33 \%$ ) considered allocating more than $20 \%$ of their income to sharia instruments. 


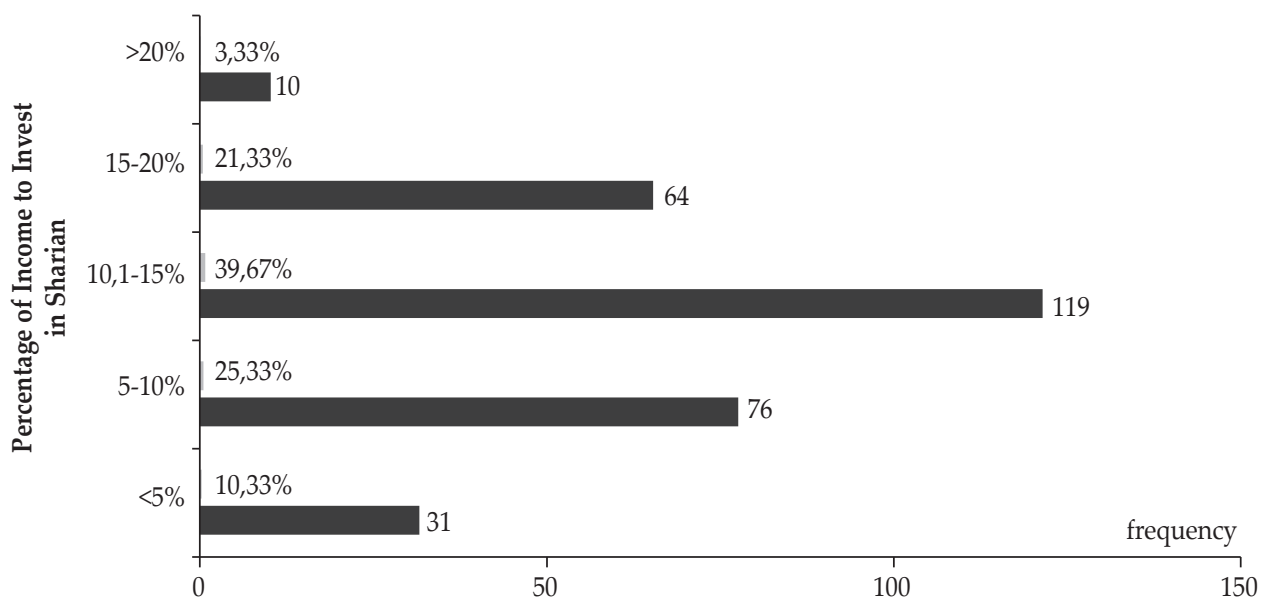

Figure 2.

Percentage of Income to Invest in Sharia

If we compare this data to the respondents' monthly income, which is dominated by income in the range Rp5,000,000-Rp9,999,999 (44.7\%) or about Rp60 million to Rp120 million per year, we obtain an estimation that most respondents will allocate at least Rp6 million (10\% of their income) to investment in sharia assets.

\subsubsection{Structural Equation Model}

Given PLS-SEM's parameter, we first conducted a validity and reliability test of the measurement model. To meet the convergent validity requirements, we eliminated two items (RK3 and SID9) with an outer loading value below 0.6, as shown in Figure 3.

Since the outer loadings with the minimum threshold value of 0.6 , we also derived the value of composite reliability; Cronbach's alpha was more than the cut-off value of 0.70 , thus indicating that the measures were robust in terms of their internal consistency reliability (Wong, 2013). The AVE values for each construct also exceeded 0.50 , thereby demonstrating the statistical significance of all items within the measurement model. Table 7 shows the validity and reliability results for the measurement model. 


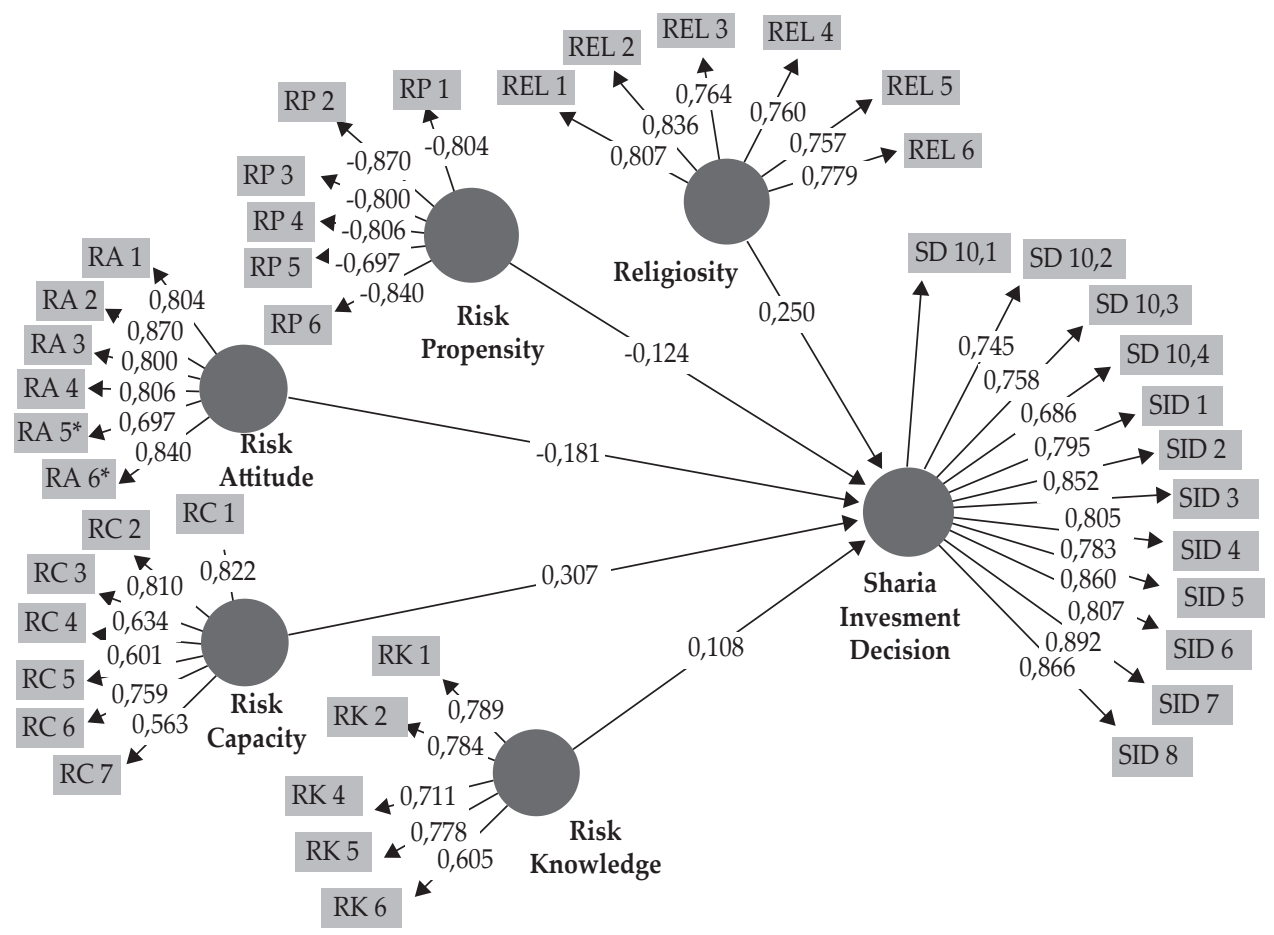

Figure 3.

Valid Measurement Model

Table 7.

Validity and Reliability Result of Measurement Model

\begin{tabular}{lccccc}
\hline Construct & Item & Loading & AVE & $\begin{array}{c}\text { Cronbach's } \\
\text { Alpha }\end{array}$ & $\begin{array}{c}\text { Composite } \\
\text { Reliability }\end{array}$ \\
\hline \multirow{5}{*}{ Risk Propensity } & RP1 & 0.804 & & & \\
& RP2 & 0.870 & & & 0.916 \\
& RP3 & 0.800 & 0.647 & 0.892 & \\
& RP4 & 0.806 & & & \\
& RP5 & 0.697 & & & \\
& RP6 & 0.840 & & & \\
Risk Attitude & RA1 & 0.705 & & & \\
& RA2 & 0.704 & & & \\
& RA3 & 0.780 & 0.519 & 0.819 & \\
& RA4 & 0.695 & & & \\
& RA5 & 0.693 & & & \\
\hline
\end{tabular}


Table 7.

Validity and Reliability Result of Measurement Model (Continued)

\begin{tabular}{|c|c|c|c|c|c|}
\hline Construct & Item & Loading & AVE & $\begin{array}{c}\text { Cronbach's } \\
\text { Alpha }\end{array}$ & $\begin{array}{l}\text { Composite } \\
\text { Reliability }\end{array}$ \\
\hline \multirow{7}{*}{ Risk Capacity } & $\mathrm{RC} 1$ & 0.822 & \multirow{7}{*}{0.512} & \multirow{7}{*}{0.841} & \multirow{7}{*}{0.878} \\
\hline & $\mathrm{RC} 2$ & 0.810 & & & \\
\hline & $\mathrm{RC} 3$ & 0.634 & & & \\
\hline & $\mathrm{RC} 4$ & 0.601 & & & \\
\hline & RC5 & 0.759 & & & \\
\hline & $\mathrm{RC} 6$ & 0.774 & & & \\
\hline & $\mathrm{RC} 7$ & 0.563 & & & \\
\hline \multirow{5}{*}{ Risk Knowledge } & RK1 & 0.709 & \multirow{5}{*}{0.519} & \multirow{5}{*}{0.781} & \multirow{5}{*}{0.842} \\
\hline & RK2 & 0.784 & & & \\
\hline & RK4 & 0.711 & & & \\
\hline & RK5 & 0.778 & & & \\
\hline & RK6 & 0.605 & & & \\
\hline \multirow{6}{*}{ Religiosity } & REL1 & 0.807 & \multirow{6}{*}{0.615} & \multirow{6}{*}{0.875} & \multirow{6}{*}{0.905} \\
\hline & REL2 & 0.836 & & & \\
\hline & REL3 & 0.764 & & & \\
\hline & REL4 & 0.760 & & & \\
\hline & REL5 & 0.757 & & & \\
\hline & REL6 & 0.779 & & & \\
\hline \multirow{12}{*}{$\begin{array}{l}\text { Sharia } \\
\text { Investment } \\
\text { Decision }\end{array}$} & SID1 & 0.795 & \multirow{12}{*}{0.650} & \multirow{12}{*}{0.951} & \multirow{12}{*}{0.957} \\
\hline & SID2 & 0.852 & & & \\
\hline & SID3 & 0.805 & & & \\
\hline & SID4 & 0.783 & & & \\
\hline & SID5 & 0.860 & & & \\
\hline & SID6 & 0.807 & & & \\
\hline & SID7 & 0.892 & & & \\
\hline & SID8 & 0.866 & & & \\
\hline & SD10.1 & 0.764 & & & \\
\hline & SD10.2 & 0.785 & & & \\
\hline & SD10.3 & 0.758 & & & \\
\hline & SD10.4 & 0.686 & & & \\
\hline
\end{tabular}

The discriminant validity results presented in Table 8 show that the square roots of the AVEs for each construct are more significant than their correlations with any other construct. Hence, these values support the discriminant validity of the constructs. 
Table 8.

Discriminant Validity (Fornell-Larcker Criterion)

\begin{tabular}{lcccccc}
\hline Construct & REL & RA & RC & RK & RK & SID \\
\hline REL & $\mathbf{0 . 7 8 4}$ & & & & & \\
RA & -0.376 & $\mathbf{0 . 7 2 0}$ & & & & \\
RC & 0.614 & -0.344 & $\mathbf{0 . 7 1 6}$ & & & \\
RK & 0.455 & -0.168 & 0.589 & 0,720 & & \\
RP & -0.179 & 0.752 & -0.211 & -0.100 & 0.805 & \\
SID & 0.578 & -0.492 & 0.613 & 0.446 & -0.381 & 0.806 \\
\hline
\end{tabular}

Note. Diagonals represent the square root of the AVE while off-diagonals represent correlations.

The next stage in the PLS-SEM was to evaluate the structural model by first analysing the values of R-squared and Q-squared. We performed a blindfolding procedure in smartPLS version 3.3 to assess the Q-square.

Table 9.

R-Squared and Q-Squared (Cross-validated Redundancy)

\begin{tabular}{lcc}
\hline Construct & R-Squared & Q-Squared \\
\hline SID & 0.517 & 0.328 \\
\hline
\end{tabular}

The result shown in Table 9 indicates that the R-squared values in this model (0.517) are classified as moderate, in line with the recommendation by Hair et al. (2014) that an R-squared value of 0.5 can be described as moderate. This finding also means that its exogenous (i.e. Risk Pack/RP, Risk Attitude/RA, Risk Capacity/ RC, Risk Knowledge/RK, and Religiosity/REL) latent variables can explain Sharia Investment Decision (SID) as an endogenous variable, by $51.7 \%$. The remaining $48.3 \%$ is explained by other variables outside the research. As for the Q-square (0.328), a value above zero indicates that the model has predictive capability (Hair et al., 2014).

\subsubsection{Hypothesis Testing Result}

Path coefficient analysis was conducted to identify the relationship between variables by performing a bootstrapping procedure with 1,000 sub-samples. Figure 4 shows the bootstrapping result of the structural model. 


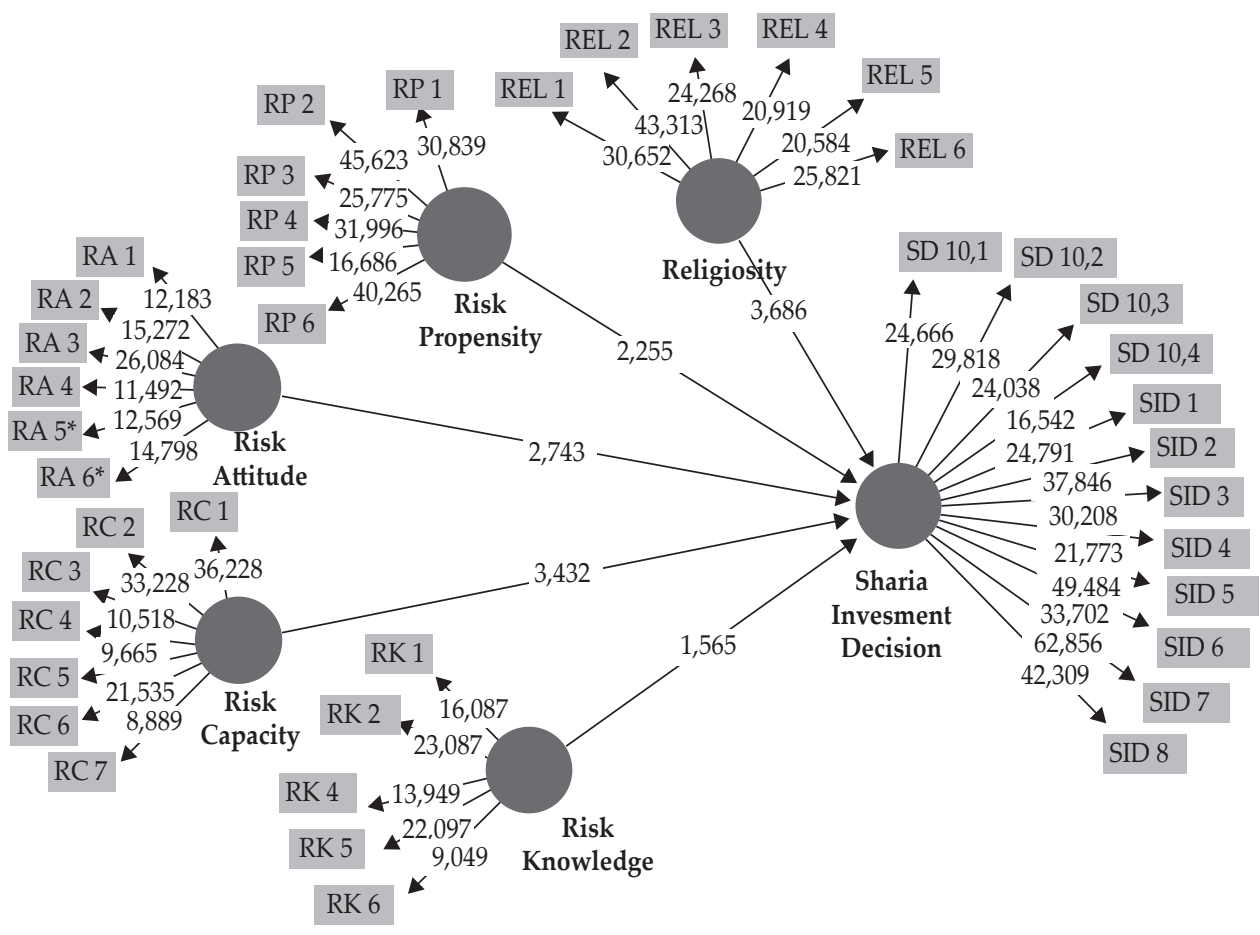

Figure 4.

Structural Model (bootstrapping)

The bootstrapping output also revealed the hypotheses testing result. A hypothesis was accepted if it had a t-statistic $>1.96$ and p-value $<0.05$. A summary of the hypotheses testing result is shown in Table 10.

Table 10.

Summary of Hypotheses Testing Result

\begin{tabular}{|c|c|c|c|c|c|c|}
\hline \multicolumn{2}{|c|}{ Hypothesis } & \multirow{2}{*}{$\begin{array}{c}\begin{array}{c}\text { Path } \\
\text { Coeff. }\end{array} \\
-0.124\end{array}$} & \multirow{2}{*}{$\frac{\text { T-stat. }}{2.255}$} & \multirow{2}{*}{$\begin{array}{c}\text { P-values } \\
0.025\end{array}$} & \multirow{2}{*}{$\begin{array}{c}\text { Conclusion } \\
\text { Significant }\end{array}$} & \multirow{2}{*}{$\begin{array}{l}\text { Decision } \\
\text { Accepted }\end{array}$} \\
\hline H1 & $\mathrm{RP} \rightarrow \mathrm{SID}$ & & & & & \\
\hline $\mathrm{H} 2$ & $\mathrm{RA} \rightarrow \mathrm{SID}$ & -0.181 & 2.743 & 0.006 & Significant & Accepted \\
\hline $\mathrm{H} 3$ & $\mathrm{RC} \rightarrow \mathrm{SID}$ & 0.307 & 3.432 & 0.001 & Significant & Accepted \\
\hline $\mathrm{H} 4$ & $\mathrm{RK} \rightarrow \mathrm{SID}$ & 0.108 & 1.565 & 0.118 & Not Significant & Not Accepted \\
\hline $\mathrm{H} 5$ & REL $\rightarrow$ SID & 0.250 & 3.686 & 0.000 & Significant & Accepted \\
\hline
\end{tabular}

As can be seen from the results of the overall hypotheses testing in Table 10, risk propensity has a significantly negative influence on Sharia investment decisions $(\beta 1=-0.124, t-s t a t>1.96, p<0.05)$. Hence the first hypothesis $(\mathrm{H} 1)$ is accepted. We also accepted the second hypothesis (H2) as we found the same result; that is, Risk Attitude has a significantly negative influence on Sharia investment decisions 
$(\beta 2=-0,181$, t-stat $>1.96, p<0.05)$. Meanwhile, Risk Capacity displayed a significant favourable influence on Sharia investment decisions $(\beta 3=0.307$, t-stat $>1.96, p<$ 0.05). Hence we also accepted the third hypothesis (H3). However, hypothesis four (H4) was rejected as risk knowledge had no significant influence on Sharia investment decisions $(\beta 4=0.108$, $t$-stat $<1.96, \mathrm{p}>0.05)$. Also, a direct positive influence was found between Religiosity and Sharia investment decisions $(\beta 5=0.250$, $t$-stat $>1.96, \mathrm{p}<0.05$ ); thus, the fifth hypothesis (H5) was accepted.

The final stage was to test the moderating effect of religiosity by performing PLS-MGA. It aimed to examine the differences in path coefficients across the various levels of religiosity. In SmartPLS software, MGA can only be compared between two different groups. All data groups selected under Group A were thus compared against all data groups selected under Group B. As there were three groups for religiosity in this study (casual, moderate and devout), we conducted three different comparisons in the analysis, as shown in Table 11.

Table 11.

Multi-Group Analysis Result

\begin{tabular}{lccccccc}
\hline \multirow{2}{*}{ Hypothesis } & \multicolumn{2}{c}{ Casual vs Moderate } & \multicolumn{2}{c}{ Casual vs Devout } & \multicolumn{2}{c}{ Moderate vs Devout } \\
\cline { 3 - 8 } & & $\begin{array}{c}\text { Path Coeff. } \\
\text { difference }\end{array}$ & p-Value & $\begin{array}{c}\text { Path Coeff. } \\
\text { difference }\end{array}$ & p-Value & $\begin{array}{c}\text { Path Coeff. } \\
\text { difference }\end{array}$ & p-Value \\
\hline H6 & RP $\rightarrow$ SID & 0.136 & 0.403 & -0.258 & 0.215 & -0.394 & $0.041^{* *}$ \\
H7 & RA $\rightarrow$ SID & -0.175 & 0.364 & 0.097 & 0.657 & 0.272 & 0.230 \\
H8 & RC $\rightarrow$ SID & 0.072 & 0.626 & -0.051 & 0.522 & -0.124 & 0.426 \\
H9 & RK $\rightarrow$ SID & 0.036 & 0.888 & -0.181 & 0.186 & -0.217 & 0.198 \\
\hline
\end{tabular}

Note. ${ }^{* *} \mathrm{p}<0.05$

Based on Table 11, we found that one difference in religiosity level (moderate vs devout) has a significant negative influence on risk propensity and Sharia investment decisions $(\beta 6=-0.394, p<0.05)$. Although this significant result applies only to the levels of moderate and devout religiosity, it does provide statistical evidence. Somehow, the different level of religiosity contributed to a weakening of the relationship between risk propensity and Sharia investment decision. Thus, we accepted hypothesis six (H6). Still, the Multi-Group Analysis was unable to provide evidence that the different levels of religiosity affect risk attitude, as well as risk capacity and risk knowledge, towards Sharia investment decisions. Hence, hypotheses seven (H7), eight (H8) and nine (H9) were not accepted.

\subsection{Analysis}

Based on the hypothesis testing, we found that the Muslim respondents' three multidimensional risks of tolerance significantly influence their decision to invest in Sharia, namely risk propensity, risk attitude and risk capacity. In contrast, risk knowledge does not have a significant influence.

Risk propensity was found to negatively influence the respondents' decision to invest in sharia assets. These results differ from those reported by Alleyne and Tracey (2011), who found that risk propensity had a positive effect on risk 
investment decisions. Muslims have a higher aversion to investing in highly risky assets compared to non-religious people (León \& Pfeifer, 2017). Muslims tend to be risk-averse, and their investment behaviour can be said to have some similarities with Islamic laws (Goel, Dwivedi, \& Jain, 2019). Therefore, Muslims with low risk propensity will consider a sharia investment as a means of reducing their risk exposure. Should their risk propensity increase, they might reduce their ownership in sharia investment instruments and seek an alternative investment that has a higher risk-return trade-off. Our hypothesis result is supported by the descriptive statistics in the crosstab tabulation, which revealed that the respondents with low risk propensity displayed a moderate-high level of Sharia investment behaviour. In contrast, those respondents with a high risk propensity exhibited a low-moderate level of Sharia investment behaviour.

Muslims' decision-making in the context of investing in Sharia assets is also negatively influenced by their risk attitude. Naveed, Khawaja, and Maroof (2020) stated that sharia investments have a lower risk exposure compared with conventional investments. Meanwhile, León and Pfeifer (2017) found that Muslims are less risk-taking in financial matters compared to those from other religions. This is why Muslims with low risk attitudes feel more inclined to invest in Sharia instruments since they have no desire to experience more significant losses or risks. Previous studies also found that risk attitude had a positive influence on investment decisions (Annamalah et al., 2019; Gakhar, 2019; Kemp et al., 2018). However, the result from our study provides new evidence that Muslims' risk attitudes negatively influence their investment decisions in Sharia instruments. It also supports the crosstab tabulation by descriptive statistics, which revealed that the respondents with low risk attitudes showed a moderate-high level of Sharia investment behaviour. Otherwise, the respondents with high risk attitudes showed a low-moderate level of Sharia investment behaviour.

Risk capacity also had a positive influence on the Muslim respondents in terms of their decision to enter into a Sharia investment. Risk capacity influences the behaviour of investors, typically by enabling them to tolerate more risks due to investor financial resources (Annamalah et al., 2019). The level of financial stability measures a Muslim's risk capacity in this study, reflecting the adequacy of their income to meet their standards of living and pay financial obligations, along with adequate insurance coverage for all possible risks. An increase in risk capacity will simultaneously increase the financial ability of Muslims to invest more in Sharia. It also supports the crosstab tabulation by descriptive statistics, which revealed that those respondents with a low risk capacity showed a low-moderate level of Sharia investment behaviour. Otherwise, the respondents with a high risk capacity showed a moderate-high level of Sharia investment behaviour.

Nonetheless, there is no evidence to suggest that risk knowledge significantly influences Muslims' Sharia investment decisions. As we have previously stated, we linked the effect of risk knowledge of a Sharia investment decision with prior studies on financial knowledge. Those previous studies showed that financial knowledge had no significant effect on investment decisions (Ademola, Musa, \& Innocent, 2019; Arifin, 2017; Gangwar \& Singh, 2018). In this research sample, we assumed that Muslims consider a sharia investment to be one with minimal risk and therefore one that permits them to have high self-confidence to invest in 
Sharia assets. This confidence can lead to well-established bias, making investors too confident about their knowledge, and ignores the risk linked to investment decisions (Madaan \& Singh, 2019). We are also of the view that the Muslim respondents' decisions were characterised by uncertainty regarding the quality and quantity of information available in the Sharia market and its associated risk. Investors thus try to deduce the information that other investors hold by observing their decisions (Fernández, Garcia-Merino, Mayoral, Santos, \& Vallelado, 2011), which can result in herding behaviour. Such herding behaviour forces investors to increase their portfolio diversification in a bid to reduce non-systematic risk (Putra, Rizkianto, \& Chalid, 2017). This is also in line with the work of Rizal and Damayanti (2019), who stated that herding behaviour exists in the Islamic stock market in Indonesia.

However, the path coefficient results indicated a positive relationship between risk knowledge and Sharia investment behaviour. Most of our respondents with a low level of risk knowledge showed a low-moderate level of sharia investment behaviour. The results indicated that only small groups of respondents with a high level of risk knowledge showed a moderate-high level of investment behaviour. A lack of adequate knowledge of risk may thus lead Muslims to invest without having conducted prior research or in-depth analysis that would allow them to make the best investment decision. This finding also indicates that risk knowledge represents only a small part of the particular knowledge that investors should have when making risky investment decisions. Therefore, this variable cannot represent general financial knowledge.

Another finding of this study is that religiosity has a significant favourable influence on Sharia investment decisions. Muslims believe that Sharia investment represents an alternative means of maximising their wealth by promoting Islamic values. Our finding is also in line with various previous studies (Jamaluddin, 2013; Mahdzan et al., 2017). The higher the investor's religiosity level, the more likely they are to opt for sharia investment schemes over conventional schemes (Abduh \& Hussin, 2018). This is also supported by the descriptive statistics in the crosstab tabulation, which revealed that the casually religious respondents showed a lowmoderate level of Sharia investment behaviour, while the devout respondents showed a moderate-high level of Sharia investment behaviour. Muslims tend to choose sharia products because they are free from riba and gharar under Islamic principles.

The levels of religiosity in this study were categorised as casual, moderate and devout. By performing a Multi-Group Analysis, we found a negative influence on risk propensity with regard to Sharia investment decisions among the moderate and devout religious individuals. Muslims with a propensity for risk are unlikely to invest in Sharia instruments since they will fail to obtain the maximum return that they would otherwise find in a very high-risk investment. However, moderate and devoutly religious individuals tend to have a lower risk propensity; hence, they are more inclined to invest in Sharia assets. This also confirms that risk propensity can change in particular circumstances (Bucciol \& Miniaci, 2018; Cordell, 2001; Sitkin \& Weingart, 1995). For Muslims, this change is partly due to their level of religiosity. 
Nevertheless, religiosity does not affect the relationship between risk capacity and Muslims' decision to invest in Sharia assets. This finding may be explained by the fact that risk capacity tends to be stable over short periods (Nobre, Grable, da Silva, \& Nobre, 2018). Hence, a Muslim's high risk capacity will not increase among those who are devout and decrease for those who are only casually religious, or vice versa, in low decision-making periods. There is also no influence between risk attitudes towards Sharia investment decisions among Muslims at different religiosity levels. This may be because a risky attitude is a form of utility function that is considered to underpin an individual's risky choices for the desired outcome (Weber, Blais, \& Betz, 2002). Therefore, risk attitude is not easily changed due to subjective factors such as religiosity but rather caused by changes in utility functions such as the available choice of more profitable investment alternatives. The level of religiosity also does not affect risk knowledge and Sharia investment decisions. This serves as evidence that risk knowledge in this research model is not a reliable predictor of a Muslim's investment decision.

\section{CONCLUSION AND RECOMMENDATION}

\subsection{Conclusion}

This study aimed to determine the effect of multidimensional risk and religiosity on the Indonesian Muslim respondents' Sharia investment decisions. The study's first key finding was that the three multidimensional risks have a significant influence on the Sharia investment decision, whereas risk propensity and risk attitude show a negative influence. Otherwise, risk capacity shows a positive influence. As for risk knowledge, there is no significant influence on Sharia investment decisions. The second finding is that religiosity, as a Muslim's nature and value, is a strong predictor of their investment decision behaviour. Moderate and devoutly religious Muslims show different levels of risk propensity. Therefore, they will have different capacities to accept the exchange between risk and return, which leaves them with more or less encouragement, preference and intention to invest in Sharia compared to any other alternative investment.

\subsection{Recommendation}

This study has revealed that multidimensional risk is one of the critical factors influencing Sharia investment decisions. Hence, just as with any other investment, an individual's risk tolerance needs to be assessed prior to making a Sharia investment decision. This should focus especially on an assessment of investor risk attitude, risk propensity and risk capacity. With one of the largest Muslim populations globally, Indonesia has a significant opportunity to expand and promote the Sharia investment ecosystem. Hence, we suggest that the Financial Services Authority (OJK) in Indonesia and other related parties develop standard risk tolerance assessments that can be used by industry players in the field of sharia investment, especially financial consulting companies.

Furthermore, this study's findings imply that financial planners should consider multiple factors, especially religiosity and risk tolerance factors, when offering advice on allocating risky assets in Muslim portfolios. Financial planners 
could therefore offer less risky sharia instruments, such as Sukuk, to very religious clients and higher-risk sharia instruments to more casually religious clients.

This study also provides a broader understanding of individual investors in terms of the importance of self-evaluating their risk tolerance before making a risky investment decision. Thus, both investors and financial planners can create more diversified portfolios with an acceptable risk exposure when considering sharia instruments as their principal investment.

Finally, no research is without limitations. The first limitation of this study is that, as our sample was limited to Muslim investors that have access to online investment, so most of the respondents were from metropolitan cities in Indonesia, with only a few respondents recruited from other cities. We also had difficulty ensuring all of the respondents were pure sharia investors; that is, those who seek to allocate the entirety of their investment funds to sharia instruments as opposed to conventionally. Findings may therefore differ between pure sharia investors and those who are not entirely Sharia. The respondents' statements may also contain some level of bias regarding their genuine willingness to take a risk if they are not purely sharia investors. Thus, future research may wish to take advantage of the actual amount of Sharia financial assets when seeking to measure Muslims' Sharia investment decisions. Secondly, the focus on multidimensional risk and religiosity as the determinant variables of the Sharia investment decision is a limitation that must be addressed. Future studies could thus incorporate other factors such as financial literacy and socio-demographic characteristics into their estimation models.

\section{REFERENCES}

Abduh, M., \& Hussin, T. M. T. T. (2018). Factors influence intention to opt for Islamic investment schemes among market players. Global Review of Islamic Economics and Business, 6(2), 91-102.

Ackert, L. F., \& Deaves, R. (2010). Behavioral finance: Psychology, decision-making, and markets. Mason: South-Western Cengage Learning.

Ademola, S. A., Musa, A. S., \& Innocent, I. O. (2019). Moderating effect of risk perception on financial knowledge, literacy and investment decision. American International Journal of Economics and Finance Research, 1(1), 34-44.

Ahmad, G. N., Warokka, A., \& Lestari, I. P. (2020). Financial risk tolerance analysis of Indonesian retail investor. Humanities $\mathcal{E}$ Social Sciences Reviews, 8(4), 852875.

Alam, N., \& Tang, K. B. (2012). Risk-taking behaviour of Islamic banks: Application of prospect theory. Qualitative Research in Financial Markets, 4(2-3), 156-164.

Alleyne, P., \& Tracey, B. (2011). Using the theory of planned behaviour and risk propensity to measure investment intentions among future investors. Journal of Eastern Caribbean Studies, 36(1), 1-20.

Annamalah, S., Raman, M., Marthandan, G., \& Logeswaran, A. K. (2019). An empirical study on the determinants of an investor's decision in unit trust investment. Economies, 7(3), 1-23.

Ardehali, P. H., Paradi, J. C., \& Asmild, M. (2005). Assessing financial risk tolerance of portfolio investors using data envelopment analysis. International Journal of Information Technology E Decision Making, 04(03), 491-519. 
Aren, S., \& Aydemir, S. D. (2015). The factors influencing given investment choices of individuals. Procedia - Social and Behavioral Sciences, 210, 126-135.

Aren, S., \& Nayman Hamamci, H. (2020). Relationship between risk aversion, risky investment intention, investment choices: Impact of personality traits and emotion. Kybernetes, 49(11), 2651-2682. Additional publication information obtained from: https://www.researchgate.net/publication/338872471_ Relationship_between_risk_aversion_risky_investment_intention_ investment_choices_Impact_of_personality_traits_and_emotion.

Arifin, A. Z. (2017). The influence of financial knowledge, control and income on individual financial behavior. European Research Studies Journal, 20(3), 635-648.

Bajo, E., Barbi, M., \& Sandri, S. (2015). Financial literacy, households' investment behavior, and risk propensity. Journal of Financial Management, Markets and Institutions, 1, 157-174.

Bank of Indonesia (2019). Sharia Economy and Finance Report.

Barata, A. (2019). Strengthening national economic growth and equitable income through sharia digital economy in Indonesia. Journal of Islamic Monetary Economics and Finance, 5(1), 145-168.

Bosner, K., \& Lakehal-Ayat, M. (2008). A comparison of risk tolerance and risk capacity among college finance students. Academy of Accounting and Financial Studies Journal, 12(1), 67-78.

Brayman, S. (2012). Defining and measuring risk capacity. Financial Services Review, 21(2), 131-148.

Bucciol, A., \& Miniaci, R. (2018). Financial risk propensity, business cycles and perceived risk exposure. Oxford Bulletin of Economics and Statistics, 80(1), 160183.

Byrne, A., Blake, D., \& Mannion, G. (2010). Pension plan decisions. Review of Behavioral Finance, 2(1), 19-36.

Combrink, S., \& Lew, C. (2019). Potential underdog bias, overconfidence and risk propensity in investor decision-making behavior. Journal of Behavioral Finance, 21(1), 1-15. Additional publication information obtained from: https://www.researchgate.net/publication/337740015_Potential_Underdog_ Bias_Overconfidence_and_Risk_Propensity_in_Investor_Decision-Making_ Behavior.

Cooper, W. W., Kingyens, A. T., \& Paradi, J. C. (2014). Two-stage financial risk tolerance assessment using data envelopment analysis. European Journal of Operational Research, 233(1), 273-280.

Cordell, D. M. (2001). RiskPACK: How to evaluate risk tolerance. Journal of Financial Planning, 14(16), 36-40.

Directorate General of Budget Financing and Risk Management Ministry of Finance (2020). Cash WakfLinked Sukuk (CWLS) SW001 Issuance Through Private Placement on March 10, 2020. Retrieved from: https:/www.djppr.kemenkeu.go.id/page/ load/2736/penerbitan-sukuk-wakaf--cash-waqf-linked-sukuk--cwls--serisw001-pada-tanggal-10-maret-2020-dengan-cara-private-placement.

Duqi, A., \& Al-Tamimi, H. (2019). Factors affecting investors' decision regarding investment in Islamic Sukuk. Qualitative Research in Financial Markets, 11(1), $60-72$. 
Dusuki, A. W., \& Abozaid, A. (2007). A critical appraisal on the challenges of realizing maqasid al-shariaah in Islamic banking and finance. IIUM Journal of Economics and Management, 15(2), 143-165.

Fernández, B., Garcia-Merino, T., Mayoral, R., Santos, V., \& Vallelado, E. (2011). Herding, information uncertainty and investors' cognitive profile. Qualitative Research in Financial Markets, 3(1), 7-33.

Firmansyah, E. A., \& Andanawari, N. (2020). Risk appetite and investment behavior: a study on Indonesia Muslim investors. Etikonomi, 19(2), 287-298.

Gakhar, D. (2019). Role of optimism bias and risk attitude on investment behaviour. Theoretical Economics Letters, 09(04), 852-871.

Gangwar, R., \& Singh, R. (2018). Analyzing factors affecting financial literacy and its impact on investment behavior among adults in India. MPRA Paper 89452, University Library of Munich, Germany. Additional publication information obtained from: https://ideas.repec.org/p/pra/mprapa/89452.html.

Ghozali, I., \& Latan, H. (2015). Partial least squares: Concepts, techniques and applications using smartPLS 3 (2nd ed.). Semarang: Diponegoro University Press.

Goel, S., Dwivedi, S., \& Jain, N. (2019). Islamic principles as a predictor of investment behaviour of Muslim investors in Delhi/NCR. IITM Journal of Management and IT, 10(2), 21-29.

Grable, J., \& Joo, S. (2004). Environmental and biopsychosocial factors associated with financial risk tolerance. Journal of Financial Counseling and Planning, 15(1), 73-82.

Gustafsson, J. (2015). Theory of generalized risk attitudes. Decision Analysis, 12(4), 205-227. Retrieved from: https://doi.org/10.1287/deca.2015.0322.

Hair, J. F., Black, W. C., Babin, B. J., \& Anderson, R. E. (2010). Multivariate data analysis (7th Edition). Hoboken: Pearson Education, Inc.

Hair, J. F., Hult, G. T. M., Ringle, C. M., \& Sarstedt, M. (2014). A primer on partial least squares structural equation modeling (PLS-SEM). Los Angeles, CA: SAGE Publications, Inc.

Hair, J. F., Sarstedt, M., Hopkins, L., \& Kuppelwieser, V. G. (2014). Partial least squares structural equation modeling (PLS-SEM): An emerging tool in business research. European Business Review, 26(2), 106-121.

Hamid, F. S., Rangel, G. J., Taib, F. M., \& Thurasamy, R. (2013). The relationship between risk propensity, risk perception and risk-taking behaviour in an emerging market. The International Journal of Banking and Finance, 10(1), 134146.

Hariharan, G. (2000). Risk tolerance and asset allocation for investors nearing retirement. Financial Services Review, 9(2), 159-170.

Henseler, J., Hubona, G., \& Ray, P. A. (2016). Using PLS path modeling in new technology research: Updated guidelines. Industrial Management and Data Systems, 116(1), 2-20.

Hess, D. W. (2012). The impact of religiosity on personal financial decisions. Journal of Religion \& Society, 14, 1-13.

Hodge, F. D., Rajgopal, S., \& Shevlin, T. (2010). Do managers value stock options and restricted stock consistent with economic theory? Contemporary Accounting Research, 26(3), 899-932. 
Holzhauer, H. M., Lu, X., McLeod, R., \& Wang, J. (2016). Risk track: The five-factor model for measuring risk tolerance. Journal of Risk Finance, 17(4), 428-445.

Hymavathi, C., Anusha, K., \& Priya, M. D. (2020). Impact of risk tolerance capacity on equity investment decisions; An empirical study on retail investors. International Journal of Disaster Recovery and Business Continuity, 11(1), 790-797.

Iddagoda, Y. A., \& Opatha, H. H. D. N. P. (2017). Religiosity: Towards a conceptualization and an operationalization. Sri Lankan Journal of Human Resource Management, 7(1), 59-69.

Imad, O. M., Razimi, M. S. bin A., \& Osman, M. F. bin. (2017). Why do we invest Islamically? A literature review on Islamic investment decision. Journal of Humanities, Language, Culture and Business (HLCB), 1(6), 1-16.

Injodey, J., \& Alex, D. (2011). Risk tolerance of investors: Developing a psychometric tool. Research Journal of Finance and Accounting, 2(2), 1-20.

Jacobs-Lawson, J., \& Hershey, D. (2005). Influence of future time perspective, financial knowledge, and financial risk tolerance on retirement saving behaviors. Financial Services Review, 14(4), 331-344.

Jamaludin, N. (2013). Religion and individual investment choice decision: The case of Malaysia. International Journal of Social Science, 4(1), 104-113.

Jamaludin, N., \& Gerrans, P. (2015). Retirement savings investment decisions: evidence from Malaysia. Journal of the Asia Pacific Economy, 20(4), 644-657.

Kahneman, D., \& Tversky, A. (1979). Prospect theory: An analysis of decision under risk. Econometrica, 47(2), 263-91.

Kannadhasan, M. (2015). Retail investors' financial risk tolerance and their risktaking behaviour: The role of demographics as differentiating and classifying factors. IIMB Management Review, 27(3), 175-184.

Kemp, S., Chan, M., Chen, Z., \& Helton, W. S. (2018). Risk attitude, perceived returns and investment choice in New Zealand. New Zealand Journal of Psychology, 47(1), 23-29.

King, J., \& Slovic, P. (2014). The affect heuristic in early judgments of product innovations. Journal of Consumer Behaviour, 13(6), 411-428.

Lampenius, N., \& Zickar, M. J. (2005). Development and validation of a model and measure of financial risk-taking. Journal of Behavioral Finance, 6(3), 129-143.

León, A. K., \& Pfeifer, C. (2017). Religious activity, risk-taking preferences and financial behaviour: empirical evidence from German survey data. Journal of Behavioral and Experimental Economics, 69(August 2017), 99-107.

Løkka, A. (2014). Optimal liquidation in a limit order book for a risk-averse investor. Mathematical Finance, 24(4), 696-727.

Lone, F. A. (2016). The objectives and achievements of Islamic finance: An analysis. In F. A. Lone, Islamic Banks and Financial Institutions (pp. 83-142). Basingstoke, UK: Palgrave Macmillan.

Madaan, G., \& Singh, S. (2019). An analysis of behavioral biases in investment decision-making. International Journal of Financial Research, 10(4), 55-67.

Mahdzan, N. S., Zainudin, R., Hashim, R. C., \& Sulaiman, N. A. (2017). Islamic religiosity and portfolio allocation: The Malaysian context. International Journal of Islamic and Middle Eastern Finance and Management, 10(3), 434-452.

Mak, M. K. Y., \& Ip, W. H. (2017). An exploratory study of investment behaviour of investors. International Journal of Engineering Business Management, 9, 1-12. 10.1177/1847979017711520. 
Mansour, W., \& Jlassi, M. (2014). The effect of religion on financial and investing decisions. In H. K. Baker \& V. Riciardi (Eds.), Wiley finance series. Investor behavior: The psychology of financial planning and investing (pp. 135-151). Hoboken, NJ: John Wiley \& Sons, Inc. Additional publication information obtained from: https://psycnet.apa.org/record/2014-13443-008.

Mantine, R., \& Jais, M. (2019). Buy, hold or sell? A study on Islamic institutional investors' investment decision behavior in bursa Malaysia. Borneo Journal of Social Sciences and Humanities, 1(1), 1-19.

Ministry of Finance Republic of Indonesia of Finance (2019). ST006 Savings Sukuk is Offered from IDR 1 Million. Retrieved from: https://www.kemenkeu.go.id/en/ publications/news/st006-savings-sukuk-is-offered-from-idr-1-million/.

Muhamad, R., Devi, S., \& Mu'min, A. G. A. (2006). Religiosity and the Malaysian Malay Muslim investors: Some aspects of investment decision. Advances in Global Business Research, 3(1), 197-206.

Naveed, F., Khawaja, I., \& Maroof, L. (2020). Are Islamic mutual funds exposed to lower risk compared to their conventional counterparts?: Empirical evidence from Pakistan. ISRA International Journal of Islamic Finance, 12(1), 69-87.

Nguyen, L., Gallery, G., \& Newton, C. (2019). The joint influence of financial risk perception and risk tolerance on individual investment decision-making. Accounting \& Finance, 59(1), 747-771.

Njuguna, P. K., Namusonge, G. S., \& Kanali, C. (2016). Influence of subjective investment knowledge on investment intention: an individual investor's perspective from Nairobi securities exchange. The International Journal of Business and Management, 4(7), 229-235.

Nobre, L. H. N., Grable, J. E., da Silva, W. V., \& Nobre, F. C. (2018). Managerial risk taking: a conceptual model for business use. Management Decision, 56(11), 2487-2501.

Octarina, E., Hartoyo, H., \& Beik, I. S. (2019). Customer purchase intention on sharia mutual fund products: a tpb approach. Journal of Consumer Sciences, 4(1), 37.

ojk.go.id. (n.d.). Sharia capital market. Retrieved from: https://www.ojk.go.id/en/ kanal/syariah/tentang-syariah/pages/pasar-modal-syariah.aspx.

Otoritas Jasa Keuangan (2019). Laporan Perkembangan Keuangan Syariah Indonesia "Sinergi dalam Membangun Ekosistem Ekonomi dan Keuangan Syariah."

Pak, O., \& Mahmood, M. (2015). Impact of personality on risk tolerance and investment decisions: A study on potential investors of Kazakhstan. International Journal of Commerce and Management, 25(4), 370-384.

Popat, D. A., \& Pandya, H. B. (2018). Evaluating the effect of financial knowledge on investment decisions of investors from Gandhinagar district. International Journal of Engineering and Management Research, 8(6), 226-237.

Putra, A. A., Rizkianto, E., \& Chalid, D. A. (2017). The analysis of herding behavior in Indonesia and Singapore stock market. Advances in Economics, Business and Management Research, 36. 11 ${ }^{\text {th }}$ International Conference on Business and Management Research (ICBMR 2017): Atlantis Press.

Raut, R. K. (2020). Past behaviour, financial literacy and investment decisionmaking process of individual investors. International Journal of Emerging Markets, 15(6), 1243-1263. 
Raut, R. K., Das, N., \& Kumar, R. (2018). Extending the theory of planned behaviour: Impact of past behavioural biases on the investment decision of Indian investors. Asian Journal of Business and Accounting, 11(1), 265-292.

Rizal, N. A., \& Damayanti, M. K. (2019). Herding behavior in the Indonesian Islamic stock market. Journal of Islamic Monetary Economics and Finance, 5(3), 673-690.

Sameen, H. S. (2017). Proposing a framework for studying influence of personality and behavioural biases on investors' performance. Global Journal of Commerce $\mathcal{E}$ Management Perspective, 6(6), 19-25.

Saputra, S. E., Natassia, R., \& Utami, H. Y. (2020). The effect of religiosity moderation with loss aversion on the investment decision of personal investors kind of stock security in Padang City. AMAR (Andalas Management Review), 4(1), 40-55.

Satvaya, S. (2017). A study on analysis of client's risk taking capacity towards investment (October Issue).

Sherif, M., \& Lusyana, D. (2016). Shariah-compliant investments and stock returns: Evidence from the Indonesian stock market. Journal of Islamic Accounting and Business Research, 8(2), 1-27.

Sindhu, K. P., \& Kumar, S. R. (2014). Influence of risk perception of investors on investment decisions. Journal of Finance and Bank Management, 2(2), 15-25.

Sitkin, S. B., \& Weingart, L. R. (1995). Determinants of risky decision-making behavior: A test of the mediating role of risk perceptions and propensity. Academy of Management Journal, 38(6), 1573-1592.

Soemitra, A. (2016). Higher objectives of Islamic investment products: Islamizing Indonesian capital market. Studia Islamika, 23(2), 237-269.

Wahl, I., \& Kirchler, E. (2020). Risk screening on the financial market (RISC-FM): A tool to assess investors' financial risk tolerance. Cogent Psychology, 7(1), 1-33.

Walkshäusl, C., \& Lobe, S. (2012). Islamic investing. Review of Financial Economics, 21(2), 53-62.

Wang, A. (2009). Interplay of investors' financial knowledge and risk taking. Journal of Behavioral Finance, 10(4), 204-213.

Weber, E. U., Blais, A., \& Betz, N. E. (2002). A domain-specific risk-attitude scale: Measuring risk perceptions and risk behaviors. Journal of Behavioral Decision Making, 15(4), 263-290.

Wong, K. K. K. (2013). Partial least squares structural equation modeling (pls-sem) techniques using smartPLS. Marketing Bulletin, 24(1), 1-32.

World Population Review (2020). Muslim population by country 2020. Retrieved from: https://worldpopulationreview.com/country-rankings/muslimpopulation-by-country.

Zhang, Y., \& Zheng, X. (2015). A study of the investment behavior based on behavioral finance. European Journal of Business and Economics, 10(1), 1-5. 
This page is intentionally left blank 